\title{
Changes in hermit crab feeding patterns in response to trawling disturbance
}

\author{
K. Ramsay ${ }^{1,2, *}$, M. J. Kaiser ${ }^{2}$, R. N. Hughes ${ }^{1}$ \\ 'Ecology Group, School of Biological Sciences, University of Wales Bangor, Deniol Road, Bangor, Gwynedd LL57 2 UW, \\ United Kingdom
}

${ }^{2}$ Ministry of Agriculture, Fisheries and Food, Directorate of Fisheries Research, Fisheries Laboratory, Benarth Road, Conwy, Gwynedd LL32 8UB, United Kingdom“

\begin{abstract}
Bottom trawling leads to the death, injury or exposure of benthic fauna, thus creating a potential source of food for predators and scavengers. We examined the behaviour of 2 sympatric species of hermit crab, Pagurus bernhardus and $P$. prideaux, in response to beam trawl disturbance. Catch numbers, body size and stomach contents of the 2 species were analysed from a treatment wayline before and after it was fished with a $4 \mathrm{~m}$ commercial beam trawl and from 2 adjacent unfished control waylines. Catch numbers of $P$. bernhardus were significantly higher on the treatment wayline 2 and $3 \mathrm{~d}$ after fishing, whilst on the fourth day they were no longer significantly different. Numbers of $P$. prideaux did not vary significantly between control or treatment waylines or with time. After fishing, the size distribution of $P$. bernhardus on the treatment wayline became skewed towards larger sizeclasses of crabs. For $3 \mathrm{~d}$ after fishing, $P$. bernhardus collected from the treatment wayline had significantly higher stomach content weights per unit body mass than those from the control area. No such difference occurred for $P$. prideaux. The diets of the 2 species were similar, including crustaceans, polychaetes and molluscs, although the ranked importance of each type of prey differed between the 2 hermit crabspecies. There was an increase in the proportion of crustaceans and polychaetes found in the stomachs of $P$. bernhardus from the treatment wayline $1 \mathrm{~d}$ after fishing. These results suggest that $P$. bernhardus migrate into recently trawled areas because they are able to benefit from feeding on the damaged or disturbed fauna generated by beam trawling. P. prideaux apparently neither move into the trawled area nor respond to the additional food source if already there, even though they have similar dietary characteristics to $P$. bernhardus.
\end{abstract}

KEY WORDS: Hermit crabs Feeding - Beam trawling . Fishing impact

\section{INTRODUCTION}

Demersal fishing methods, particularly beam trawling, have been shown to result in the mortality of some non-target benthic species (van Beek et al. 1990. Bergman \& Santbrink 1994, Fonds 1994, Santbrink \& Bergman 1994, Kaiser \& Spencer 1995). A proportion of the non-commercial and undersized animals from the catch die, despite being returned to the sea (Kaiser \& Spencer 1995j and many animals are also damaged by the trawl but remain on the seabed (Bergman \& Santbrink 1994). This latter type of mortality has been

-E-mail:k.ramsay@dfr.maff.gov.uk

- Address for correspondence described as 'non-catch mortality' (Bergman \& Santbrink 1994, Santbrink \& Bergman 1994). The tickler chains of a beam trawl are designed to penetrate the surface of the sediment, thereby increasing the catch of the target species, sole Solea solea and plaice Pleuronectes platessa, but also disturbing and damaging infaunal animals, such as the burrowing heart urchin Echinocardium cordatum (Bergman \& Hup 1992) and the tube dwelling amphipod Ampelisca spinipes (Kaiser \& Spencer 1994). Other animals may be crushed by the beam shoes, chain mat or cod-end as the trawl passes over them. Small animals may enter the net and escape through the mesh but still be damaged during this process (Craeymeersch 1994, Fonds 1994, Kaiser \& Spencer 1995) 
Various studies have investigated the consumption of fisheries discards by predatory or scavenging birds, fishes and crustacea (Wassenberg \& Hill 1987, 1990, Furness et al. 1988, Hudson \& Furness 1988, Blaber \& Wassenberg 1989, Berghahn 1990) but fewer have examined the consumption of damaged fauna in the tracks of a trawl. Kaiser \& Spencer (1994) found that the composition of the diets of gurnards and whiting altered in a fished area and suggested that these fish were feeding on fauna damaged by the trawl. More recent studies (Kaiser \& Spencer 1996a, K. Ramsay unpubl. data), have found that other scavengers such as starfish Asterias rubens and hermit crabs Pagurus spp. are attracted to areas disturbed by trawling

Pagurus bernhardus (L.) is widely distributed in European waters and occurs from the littoral zone to depths of $100 \mathrm{~m}$ (Pike \& Williamson 1959). P. bernhardus apparently exhibits a variety of feeding methods including scavenging (Jackson 1913, Nickell \& Moore 1992, Kaiser \& Spencer 1996a), deposit feeding (Orton 1927) and filter feeding (Gerlach et al. 1976, Erri Babu 1988) Less is known. about the biology of Pagurus prideaux Leach which is sympatric with $P$. bernhardus at the study site described in this paper. The most striking external difference between these species is that $P$. bernhardus occupies empty gastropod shells, whereas the abdomen of $P$, prideaux is usually cloaked by the anemone Adamsia carciniopados (Pike \& Williamson 1959).

The present study investigated whether (1) these 2 hermit crab species migrate into trawled areas, (2) crabs in trawled areas consume more food than those in surrounding untrawled areas and (3) their diets change as a result of trawling.

\section{METHODS}

The experimental site used in this study was located ca 9 miles off the northeast coast of Anglesey, Irish Sea (Kaiser \& Spencer 1996b) and has a water depth of ca $40 \mathrm{~m}$. This site is rarely visited by commercial fishing vessels and no fishing other than our experimental fishing took place during the course of this study. In April 1995 a $2.8 \mathrm{~m}$ beam trawl designed to maximise epibenthic catch (Kaiser et al. 1994) was used to sample an epibenthic community at time intervals before and after fishing a $1.5 \mathrm{~km}$ wayline with a commercial $4 \mathrm{~m}$ beam trawl. The $2.8 \mathrm{~m}$ beam trawl had a square mesh cod-end with a knot to knot distance of $4 \mathrm{~cm}$. Catch numbers of epibenthic species were recorded and 2 hermit crab species, Pagurus bernhardus and $P$. prideaux, were collected and stored frozen for later analysis in the laboratory.
To create a trawling disturbance, the treatment wayline was fished 10 times using a $4 \mathrm{~m}$ commercial beam trawl fitted with a chain matrix, flip-up ropes and an $80 \mathrm{~mm}$ diamond mesh cod-end. A Differential Global Positioning System (DGPS), which gives a position accurate to within $5 \mathrm{~m}$, used in conjunction with a navigational package, Sextant ${ }^{2}$, on board the ship ensured accurate trawling. Previous experience had shown that towing the $4 \mathrm{~m}$ beam trawl 10 times would ensure that on average a corridor with a width of 30 to $40 \mathrm{~m}$ was completely fished once (Kaiser \& Spencer 1996b)

The experimental design was such that a treatment (fished) wayline and 2 control waylines were sampled, once before fishing the treatment wayline with the $4 \mathrm{~m}$ beam trawl, and then for $4 \mathrm{~d}$ after fishing at approximately $24 \mathrm{~h}$ intervals. The control waylines ran parallel to the treatment wayline at a distance of $250 \mathrm{~m}$ on either side. Six replicate tows were made with the $2.8 \mathrm{~m}$ beam trawl, each with a duration of $3.5 \mathrm{~min}$, on each wayline on each sampling occasion (18 tows per day). The exception to this was the final day (28 April 1995) when, due to time constraints, only 1 control wayline and the treatment wayline were fished, each 5 times. To minimise temporal differences in sampling between waylines the following pattern of sampling was adopted: 2 tows were carried out on 1 wayline, then on a second wayline (the first 2 waylines to be sampled were chosen at random), and then on the remaining wayline. This pattern was repeated twice until 6 tows had been completed on each wayline. No attempt was made to sample at identical positions on consecutive days and therefore the sampling can be considered to have been at random points along each wayline. The times of each period of fishing are shown in Table 1. Catches from both the $2.8 \mathrm{~m}$ beam trawl and the $4 \mathrm{~m}$ beam trawl were discarded at a distance of ca $4 \mathrm{~km}$ away from the experimental area to avoid the possible confounding effects of discarded carrion landing on the seabed.

The start and finish position of each tow were recorded from the DGPS at the moment the trawl reached the seabed and the moment the winch began to retrieve the net. Distance towed over the seabed was then calculated and catch numbers standardised to numbers per $1000 \mathrm{~m}^{2}$. Differences between mean catch numbers were analysed using analysis of variance on $\log (x+1)$-transformed data. A few tows have been omitted from the analysis where problems with the DGPS meant that it was not possible to ascertain tow length.

Hermit crabs were collected from each $2.8 \mathrm{~m}$ beam trawl catch and stored frozen. In the laboratory, crabs were defrosted and, for each individual, thorax length was measured to $\pm 1 \mathrm{~mm}$, sex was noted and 
Table 1 Times and duration of sampling periods with the $2.8 \mathrm{~m}$ beam trawl and fishing with the $4 \mathrm{~m}$ beam trawl

\begin{tabular}{|c|c|c|c|}
\hline $\begin{array}{l}\text { Date } \\
\text { (1995) }\end{array}$ & $\begin{array}{c}\text { Fishing/sampling } \\
\text { gear used }\end{array}$ & Waylines sampled & $\begin{array}{l}\text { Time period } \\
\text { (h GMT) }\end{array}$ \\
\hline $24 \mathrm{Apr}$ & $2.8 \mathrm{~m}$ beam trawl & 1 treatment, 2 control & $08: 19-13: 23$ \\
\hline $24 \mathrm{Apr}$ & $4 \mathrm{~m}$ beam trawl & & $22: 01-03: 57$ \\
\hline $25 \mathrm{Apr}$ & $2.8 \mathrm{~m}$ beam trawl & 1 treatment, 2 control & $05: 23-10: 38$ \\
\hline $26 \mathrm{Apr}$ & $2.8 \mathrm{~m}$ beam trawl & 1 treatment, 2 control & $05: 12-11: 04$ \\
\hline $27 \mathrm{Apr}$ & $2.8 \mathrm{~m}$ beam trawl & 1 treatment, 2 control & $05: 02-13: 07$ \\
\hline $28 \mathrm{Apr}$ & $2.8 \mathrm{~m}$ beam trawl & 1 treatment, 1 control & $05: 03-08: 03$ \\
\hline 27 Oct & $2.8 \mathrm{~m}$ beam trawl & 1 treatment, 1 control & $11: 41-18: 49$ \\
\hline $27 \mathrm{Oct}$ & $4 \mathrm{~m}$ beam trawl & & $19: 54-01: 40$ \\
\hline $28 \mathrm{Oct}$ & $2.8 \mathrm{~m}$ beam trawl & 1 treatment, 1 control & $07: 07-10: 57$ \\
\hline 29 Oct & $2.8 \mathrm{~m}$ beam trawl & 1 treatment, 1 control & $08: 49-11: 50$ \\
\hline $30 \mathrm{Oct}$ & $2.8 \mathrm{~m}$ beam trawl & 1 treatment, 1 control & $08: 47-13: 16$ \\
\hline
\end{tabular}

the stomach was dissected out. For crabs with undamaged legs and chelae, the height of the right cheliped was determined and the wet body weight (without the shell) was also recorded. The stomach contents were preserved in $70 \%$ alcohol and later examined under a low-power dissecting microscope. The points method (Hynes 1950, Williams 1981) was used to estimate volumetric abundance of different phyla in the stomach contents. Thus each phylum was given $1,2,4,8,16$ or 32 points based on its estimated relative volume in the gut. Unidentifiable components of the stomach contents were grouped separately. Percentage points for each phylum were then calculated (see Freire et al. 1991):

$$
\% \text { points }_{j}=\frac{\sum_{j=1}^{n} a_{j i}}{\sum_{i=1}^{n} a_{i}} \times 100
$$

where $a_{j i}$ is the number of points assigned to phylum $j$ in stomach $i, \mathrm{n}$ is the number of hermit crabs in a group and $a_{i}$ is the total number of points for stomach $i$. Percentage points were calculated for each hermit crab species for the control samples and the treatment samples for each day. The stomach contents of 20 randomly chosen crabs were analysed per treatment (fished or unfished control) on each day. Data from these 20 crabs were pooled prior to further analyses. Cluster analysis and multidimensional scaling (MDS) were then carried out on $\ln (x+1)$-transformed data using data for all phyla (including unidentified material). Similarity between samples was determined using the Bray-Curtis index of similarity and the group average linkage method. An a priori analysis of similarities test (ANOSIM) was performed to investigate whether the diets of the 2 species differed significantly. The PRIMER statistical software package was used for this analysis (Clarke \& Warwick 1994). To give an indica- tion of diversity of the diets, mean number of phyla per stomach and the Shannon diversity index were calculated for each hermit crab species.

To determine their dry weight, stomach contents were filtered lusing numbered pre-dried and weighed filter papers), placed in a drying oven at $60^{\circ} \mathrm{C}$ for $24 \mathrm{~h}$ and weighed to an accuracy of $0.01 \mathrm{mg}$. Differences in the relationship between crab size (thorax length) and dry weight of stomach contents were examined using analysis of covariance (ANCOVA) on In-transformed data, treating crab size as a covariate and fishing disturbance (unfished control or fished treatment) as a factor.

In October 1995 the sampling protocol was repeated at the same site. The beam trawl used for sampling was of a similar design to the one used in April but was not identical. On this occasion crabs were not preserved for stomach contents analysis and only 1 control wayline was sampled. The primary objective was to obtain a size-frequency distribution, based on the chelal height of the right cheliped, for crabs from the control and treatment wayline before and after fishing for both Pagurus bernhardus and $P$. prideaux. Cheliped height was used as it is quick to measure; removing crabs from their shells in order to measure thorax length would be costly in terms of time and often be fatal for the animal. Measurements made during the stomach content sampling showed strong correlation between cheliped height, crab weight and thorax length (regression equations generally had an adjusted $\mathrm{R}^{2}$ value of around 0.90 ). When catch numbers became very large, random subsampling was carried out, such that when over 150 individuals had been measured subsequent catches were not sampled. Differences in size-frequency distributions between the control and treatment waylines for each day were tested using the Kolmogorov-Smirnov test.

\section{RESULTS}

\section{Catch numbers of hermit crabs}

April 1995. For Pagurus bernhardus catch numbers were significantly higher on the commercially trawled wayline 2 and $3 \mathrm{~d}$ after fishing (Table 2). On the fourth day after fishing, the difference between the fished wayline and the unfished control area was no longer significant, although numbers were still higher on the fished wayline (Table 2). The mean number of crabs on the control wayline was very similar throughout the 
Table 2. Pagurus bernhardus, P. prideaux. April 1995. Densithes of crabs on the control and treatment lines at time periods before and after fishing the treatment wayline with a $4 \mathrm{~m}$ beam trawl, including $95 \%$ confidence limits (assuming a Poisson distribution). Results of ANOVA between catch densities (log transformed) on the control and treatment waylines [ns: not significant $(p>0.05)]$

\begin{tabular}{|c|c|c|c|c|c|}
\hline \multirow[t]{2}{*}{$\begin{array}{l}\text { Days before/ } \\
\text { after fishing }\end{array}$} & \multicolumn{2}{|c|}{$\begin{array}{l}\text { Average number } \\
\text { caught per } 1000 \mathrm{~m}^{2}\end{array}$} & \multicolumn{3}{|c|}{ ANOVA } \\
\hline & Control & Treatment & $F$ & $\mathrm{df}$ & $\mathrm{p}$ \\
\hline \multicolumn{6}{|c|}{ Pagurus bernhardus } \\
\hline Before & $9.7 \pm 1.8$ & $4.5 \pm 1.9$ & 0.33 & 14 & ns \\
\hline $1 \mathrm{~d}$ after & $5.0 \pm 1.3$ & $12.8 \pm 2.9$ & 2.04 & 16 & ns \\
\hline $2 \mathrm{~d}$ after & $7.1 \pm 1.5$ & $81.8 \pm 7.9$ & 24.59 & 15 & $<0.001$ \\
\hline $3 \mathrm{~d}$ after & $7.6 \pm 1.4$ & $60.5 \pm 6.2$ & 20.98 & 18 & $<0.001$ \\
\hline $4 \mathrm{~d}$ after & $6.0 \pm 2.1$ & $40.6 \pm 5.6$ & 3.16 & 8 & ns \\
\hline \multicolumn{6}{|c|}{ Pagurus prideaux } \\
\hline Before & $7.3 \pm 1.6$ & $6.4 \pm 2.2$ & 0.00 & 14 & ns \\
\hline $1 \mathrm{~d}$ after & $4.9 \pm 1.3$ & $6.3 \pm 2.0$ & 1.29 & 16 & ns \\
\hline 2 d after & $9.2 \pm 1.7$ & $13 . \overline{7} \pm 3.2$ & 2.66 & 15 & 175 \\
\hline 3 d after & $8.5 \pm 1.5$ & $6.3 \pm 2.0$ & 0.03 & 18 & ns \\
\hline $4 \mathrm{~d}$ after & $8.6 \pm 2.6$ & $4.8 \pm 1.9$ & 3.24 & 8 & ns \\
\hline
\end{tabular}

experiment (range $5.0 \pm 1.3$ to $9.7 \pm 1.8$ ) For $P$. prideaux there were no significant differences between numbers on the control and treatment waylines.

October 1995. For Pagurus bernhardus catch numbers were significantly higher on the commercially trawled wayline $2 \mathrm{~d}$ after fishing (Table 3). For $P$. prideaux numbers were significantly higher on the control wayline on the third day after fishing (Table 3). Catch numbers of both species were higher in October than in April; this was probably a seasonal effect.
Table 3. Pagurus bernhardus, P. prideaux. October 1995 Densities of crabs on the control and treatment lines at time periods before and after fishing the treatment wayline with a $4 \mathrm{~m}$ beam trawl, including $95 \%$ confidence limits (assuming a Poisson distribution). Results of ANOVA between catch densities (log transformed) on the control and treatment waylines [ns: not significant $(p>0.05)$ ]

\begin{tabular}{|c|c|c|c|c|c|}
\hline \multirow[t]{2}{*}{$\begin{array}{l}\text { Days before } \\
\text { after fishing }\end{array}$} & \multicolumn{2}{|c|}{$\begin{array}{l}\text { Average number } \\
\text { caught per } 1000 \mathrm{~m}^{2}\end{array}$} & \multicolumn{3}{|c|}{ ANOVA } \\
\hline & Control & Treatment & $F$ & $\mathrm{df}$ & $\mathrm{p}$ \\
\hline \multicolumn{6}{|c|}{ Pagurus bernhardus } \\
\hline Before & $23.3 \pm 3.0$ & $36.1 \pm 5.3$ & 1.54 & 13 & ns \\
\hline $1 \mathrm{~d}$ after & $48.4 \pm 5.6$ & $73.6 \pm 7.5$ & 2.12 & 9 & ns \\
\hline 2 d after & $38.8 \pm 5.0$ & $151.0 \pm 9.8$ & 15.11 & 10 & $<0.01$ \\
\hline $3 \mathrm{~d}$ after & $44.4 \pm 5.3$ & $72.6 \pm 6.8$ & 0.34 & 10 & ns \\
\hline \multicolumn{6}{|c|}{ Pagurus prideaux } \\
\hline Before & $20.0 \pm 2.8$ & $40.5 \pm 5.6$ & 2.32 & 13 & ns \\
\hline $1 \mathrm{~d}$ after & $47.9 \pm 5.5$ & $44.7 \pm 5.9$ & 0.13 & 9 & ns \\
\hline $2 d$ after & $56.4 \pm 6.0$ & $37.9 \pm 4.9$ & 0.83 & 10 & ns \\
\hline 3 d after & $54.0 \pm 5.9$ & $21.1 \pm 3.7$ & 10.99 & 10 & $<0.01$ \\
\hline
\end{tabular}

\section{Size-frequency distributions}

Before fishing the size-frequency distribution of Pagurus bernhardus on the treatment wayline was not significantly different from that on the control wayline (Fig. 1). However, after trawling with the commercial gear the size distribution of $P$. bernhardus on the treatment wayline became skewed towards larger size classes of crabs. This difference was significant for each of the 3 days following fishing (Fig. 1). For P. prideaux significant differences were found between size distributions on the

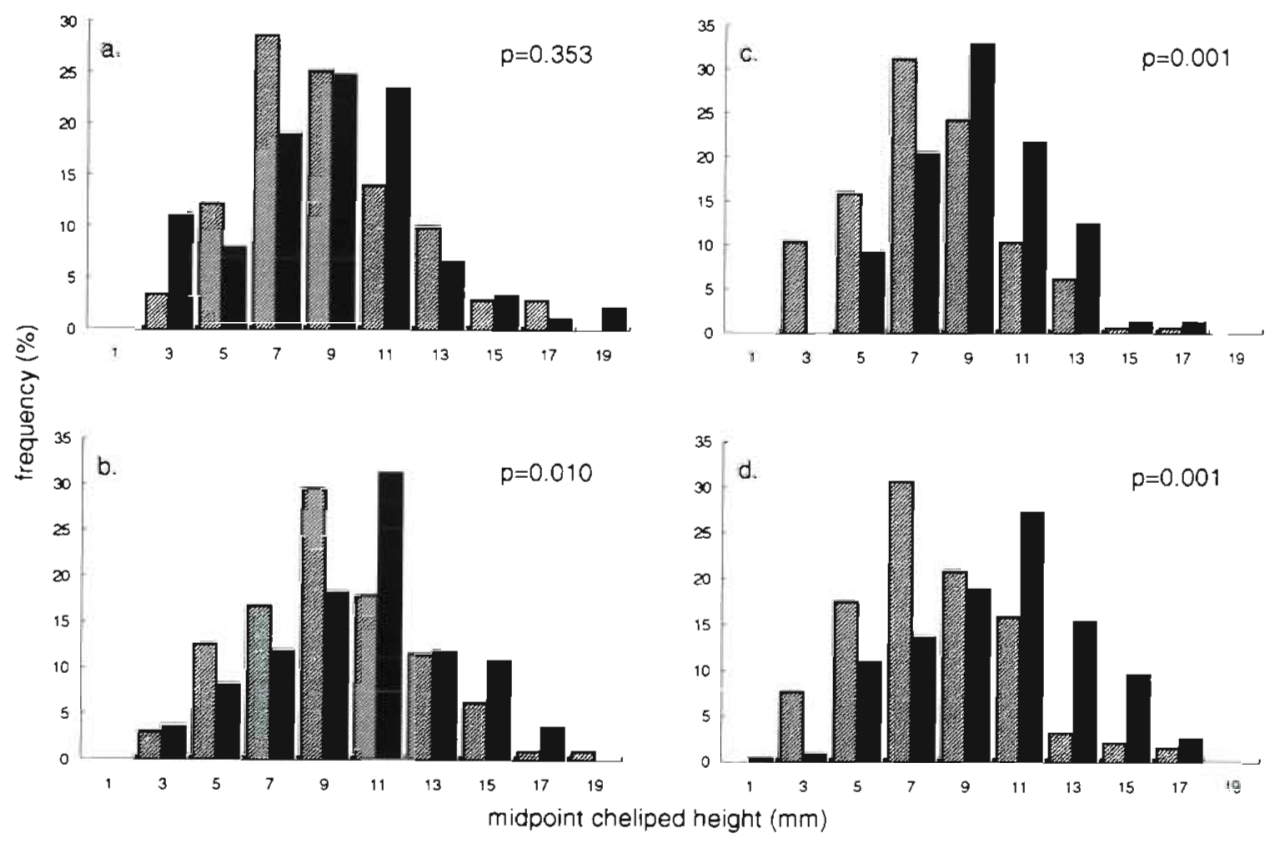

Fing. 1. Pagurus bernhardus. Size-frequency distributions of hermit crabs caught before and after fishing on the

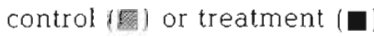
waylines. (a) Before fishing (b) 1 d, (c) 2 d, (d) 3 d after fishing. Also showing results of the Kolmogorov-Smirnov test (p) 
Fig. 2. Pagurus prideaux Size-frequency distributions of hermit crabs caught before and after fishing on the control (필 $)$ or treatment ( waylines. (a) Before fishing; (b) 1 d, (c) 2 d, (d) 3 d after fishing. Also showing results of the Kolmogorov-Smirnov test $(p)$
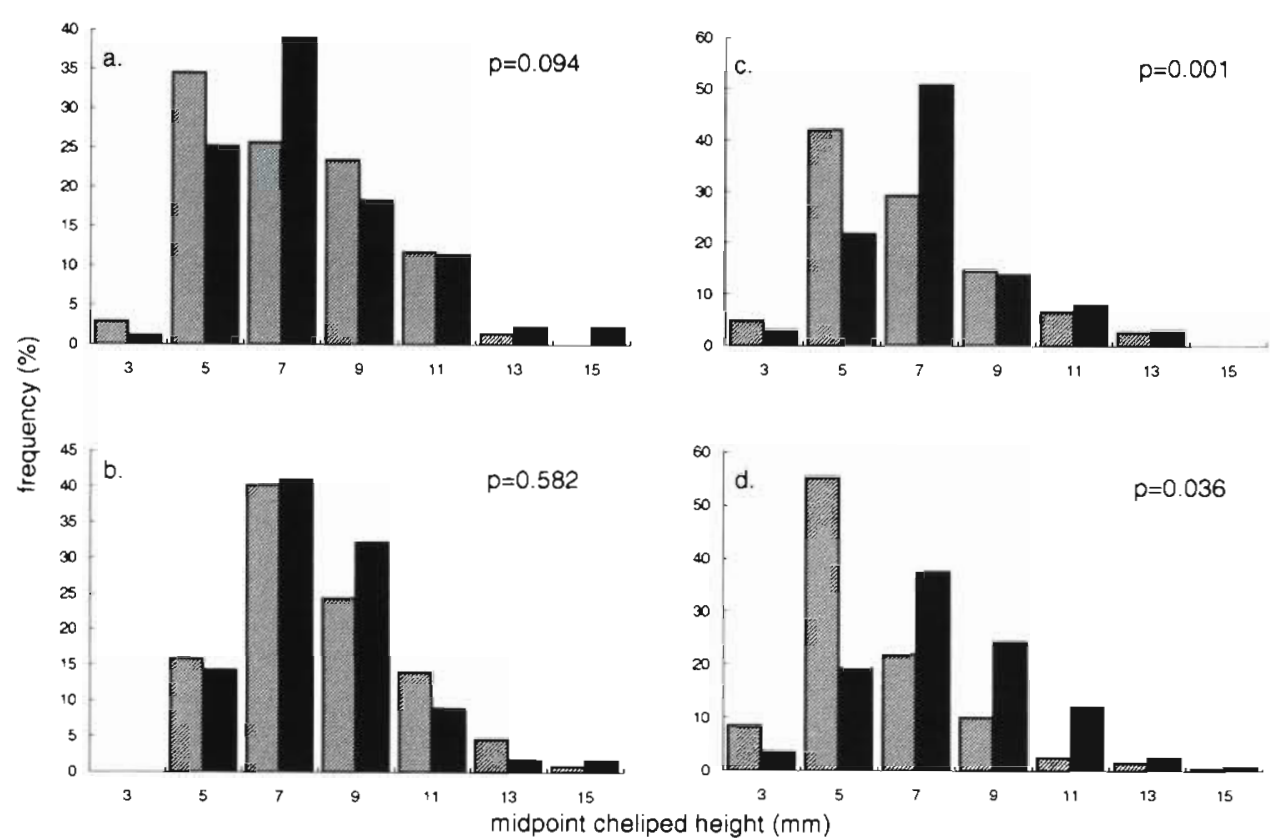

control and treatment waylines on the second and third day after fishing (Fig. 2). However, these differences appear to be due to increased numbers of small crabs on the control wayline, rather than an increase in the numbers of large crabs on the treatment wayline.

\section{Food intake}

Pagurus bernhardus. The relationship between ln(thorax length) and in(dry weight of stomach con-

Table 4. Pagurus bernhardus, $P$. prideaux. Test for differences between waylines (control or treatment) in the relationship between weight of stomach contents and crab size. ANCOVA on model: ln[dry weight of stomach contents (mg)] $=\mathrm{a}+$ b. In[thorax length $(\mathrm{mm})]$ using wayline as a factor For fitted models, see Figs. 3 \& 4

\begin{tabular}{|c|c|c|c|}
\hline \multirow{2}{*}{$\begin{array}{l}\text { Days before/ } \\
\text { after fishing }\end{array}$} & \multicolumn{3}{|c|}{ ANCOVA, $p>F$} \\
\hline & Model & $\begin{array}{c}\text { Different } \\
\text { intercepts }\end{array}$ & $\begin{array}{c}\text { Different } \\
\text { slopes }\end{array}$ \\
\hline \multicolumn{4}{|c|}{ Pagurus bernhardus } \\
\hline Before & 0.0009 & 0.7593 & 0.8377 \\
\hline $1 \mathrm{~d}$ after & 0.0001 & 0.0488 & 0.6183 \\
\hline 2 d after & 0.0001 & 0.0156 & 0.1174 \\
\hline 3 d after & 0.0057 & 0.0020 & 0.0635 \\
\hline $4 d$ after & 0.0001 & 0.3069 & 0.3738 \\
\hline \multicolumn{4}{|c|}{ Pagurus prideaux } \\
\hline Before & 0.0001 & 0.7520 & 0.0940 \\
\hline $1 \mathrm{~d}$ after & 0.0022 & 0.2224 & 0.7237 \\
\hline $2 \mathrm{~d}$ after & 0.0001 & 0.8148 & 0.0909 \\
\hline $3 \mathrm{~d}$ after & 0.7757 & 0.0921 & 0.8601 \\
\hline $4 d$ after & 0.1522 & 0.6418 & 0.7056 \\
\hline
\end{tabular}

tents) was linear (Fig. 3). Before fishing had taken place there were no significant differences between models for the control or treatment waylines (Table 4). However, for $3 \mathrm{~d}$ following beam trawling there were significant differences between intercepts of the control and treatment samples, with the intercept for the fished wayline being higher than that for the control wayline (Fig 3). On the final (fourth) day there were no significant differences in the intercepts or slopes (Fig. 3).

Pagurus prideaux. The relationship between $\ln ($ thorax length) and $\ln$ (dry weight of stomach contents) was found to be linear before fishing and for $2 \mathrm{~d}$ after fishing. The intercepts and slopes were not significantly different between lines (Table 4) and therefore a common line was fitted to the data (Fig. 4). On the third and fourth days after fishing the model was not significant (Table 4) and therefore no line was fitted (Fig. 4)

\section{Hermit crab diets}

The following phyla were observed in the stomach contents: Crustacea (amphipods, copepods, isopods, body parts of larger unidentified Crustacea), Annelida (polychaetes), Mollusca (bivalves, gastropods), Cnidaria (hydroids), Echinodermata (echinoids and holothurians), Bryozoa, Sarcomastigophora (foraminiferans). Also observed were eggs of unknown origin (in 3 stomachs) and a single fish scale. Identification to species level was rarely possible due to the macerated nature of the digesta. In both species the most common phyla were Crustacea, Annelida and Mollusca (Tables 5 \& 6). 

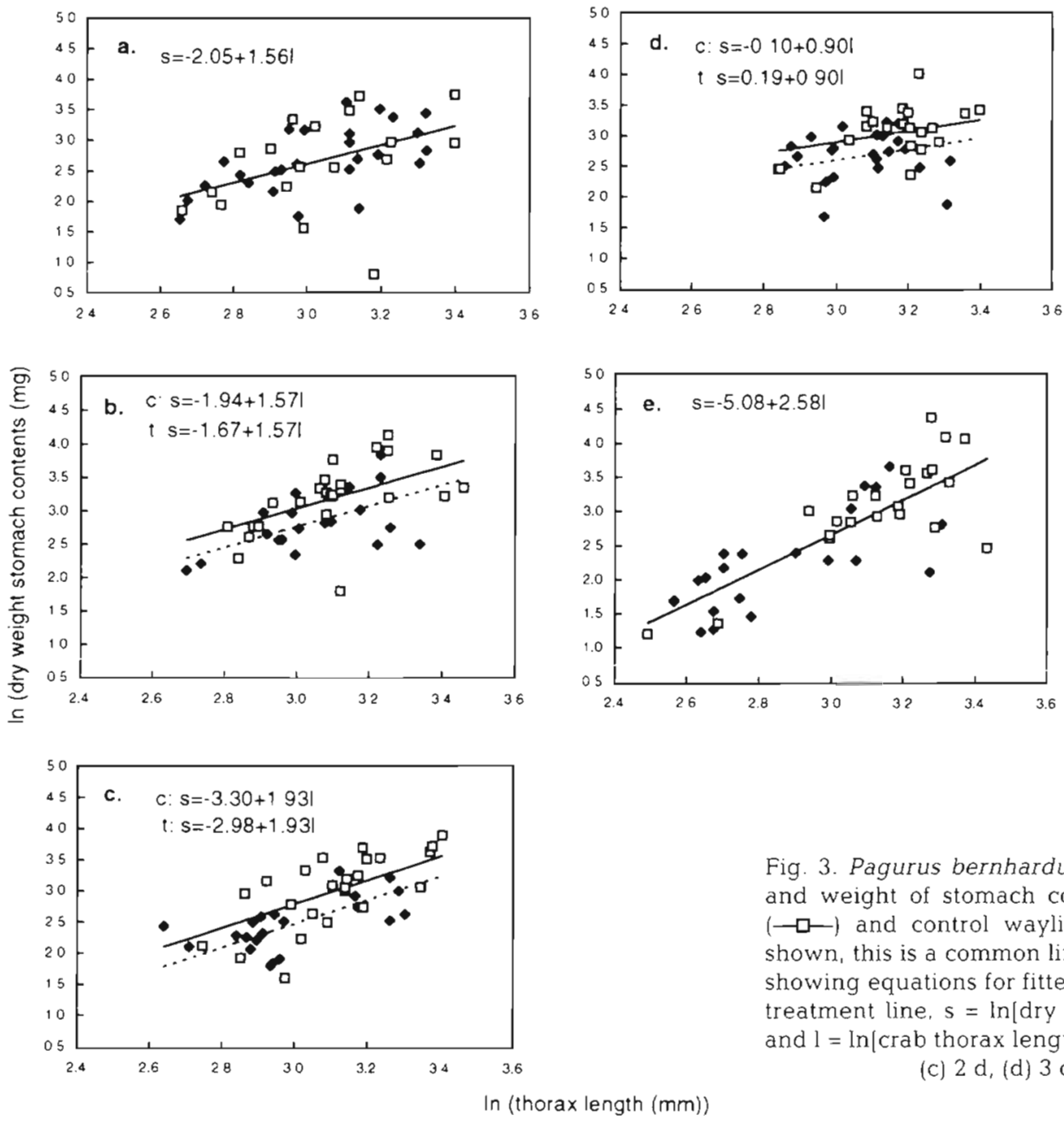

Fig. 3. Pagurus bernhardus. Relationship between crab size and weight of stomach contents for the treatment wayline $(\rightarrow--)$ and control wayline $(\cdots \cdots)$; where only 1 line is shown, this is a common line fitted to the whole dataset. Also showing equations for fitted line(s) where $\mathrm{c}=$ control line, $\mathrm{t}=$ treatment line, $s=\ln [$ dry weight of stomach contents (mg)] and $1=\ln [$ crab thorax length $(\mathrm{mm})]$. (a) Before fishing; (b) $1 \mathrm{~d}$. (c) $2 \mathrm{~d}$, (d) $3 \mathrm{~d}$, (e) $4 \mathrm{~d}$ after fishing

Cluster analysis and subsequent multidimensional scaling (MDS) of the stomach contents data (percentage points) showed that the diets of Pagurus bernhardus and $P$. prideaux fell into 2 significantly different groups (Fig. 5, ANOSIM, R $=0.729, \mathrm{p}<0.001$ ). All phyla observed were found in both species' stomachs,

with the exception of a fish scale which was found in a single $P$. bernhardus. Therefore the difference in dietary composition is probably attributable to differences in the proportions of phyla consumed. $P$. prideaux appeared to consume a larger proportion of molluscs and crustaceans and a smaller proportion of

Table 5. Pagurus bernhardus. Diet composition. Percentage points for each group in the stomach contents

\begin{tabular}{|c|c|c|c|c|c|c|c|c|c|c|c|}
\hline $\begin{array}{l}\text { Days before/ } \\
\text { after fishing }\end{array}$ & Wayline & $\begin{array}{l}\text { Crusta- } \\
\text { ceans }\end{array}$ & $\begin{array}{c}\text { Poly- } \\
\text { chaetes }\end{array}$ & Molluscs & $\begin{array}{l}\text { Echino- } \\
\text { derms }\end{array}$ & Hydroids & $\begin{array}{l}\text { Bryo- } \\
\text { zoans }\end{array}$ & $\begin{array}{l}\text { Forami- } \\
\text { niferans }\end{array}$ & Eggs & Fish & $\begin{array}{l}\text { Unidenti- } \\
\quad \text { fied }\end{array}$ \\
\hline \multirow[t]{2}{*}{ Before } & Control & 5.2 & 4.3 & 10.4 & 0.8 & 1.9 & 1.9 & 0.3 & 0.0 & 0.0 & 75.3 \\
\hline & Treatment & 4.2 & 8.9 & 3.9 & 0.0 & 1.5 & 1.8 & 0.3 & 0.0 & 0.0 & 79.4 \\
\hline \multirow[t]{2}{*}{$1 \mathrm{~d}$ after } & Control & 17.5 & 6.8 & 7.4 & 1.3 & 1.7 & 2.2 & 0.3 & 1.3 & 0.0 & 61.5 \\
\hline & Treatment & 33.2 & 29.5 & 3.4 & 2.3 & 0.2 & 0.6 & 0.1 & 0.0 & 0.0 & 30.7 \\
\hline \multirow[t]{2}{*}{$2 \mathrm{~d}$ after } & Control & 4.7 & 7.6 & 3.7 & 0.6 & 2.5 & 1.5 & 0.0 & 0.0 & 0.0 & 79.3 \\
\hline & Treatment & 8.1 & 16.8 & 9.1 & 4.7 & 0.4 & 1.4 & 0.3 & 0.0 & 0.0 & 59.1 \\
\hline \multirow[t]{2}{*}{$3 \mathrm{~d}$ after } & Control & 6.8 & 5.5 & 11.3 & 5.1 & 3.7 & 1.3 & 0.1 & 0.0 & 0.0 & 66.2 \\
\hline & Treatment & 2.2 & 14.0 & 12.8 & 6.2 & 1.7 & 2.9 & 0.2 & 0.0 & 0.0 & 60.0 \\
\hline \multirow[t]{2}{*}{$4 \mathrm{~d}$ after } & Control & 6.3 & 9.3 & 4.3 & 2.0 & 1.3 & 2.3 & 0.5 & 0.0 & 0.0 & 74.0 \\
\hline & Treatment & 4.2 & 10.0 & 6.4 & 2.0 & 2.9 & 3.5 & 0.3 & 0.0 & 0.1 & 70.4 \\
\hline
\end{tabular}



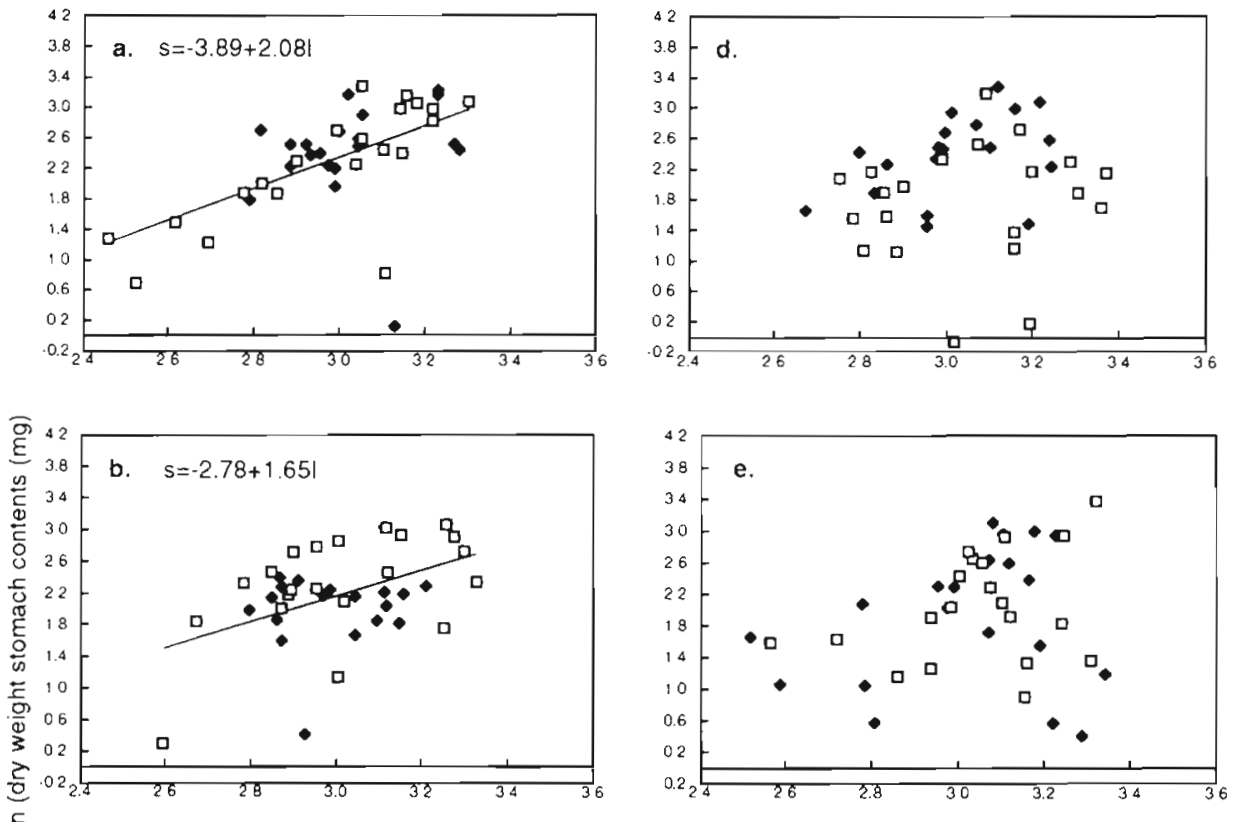

$\underline{\underline{ }}$

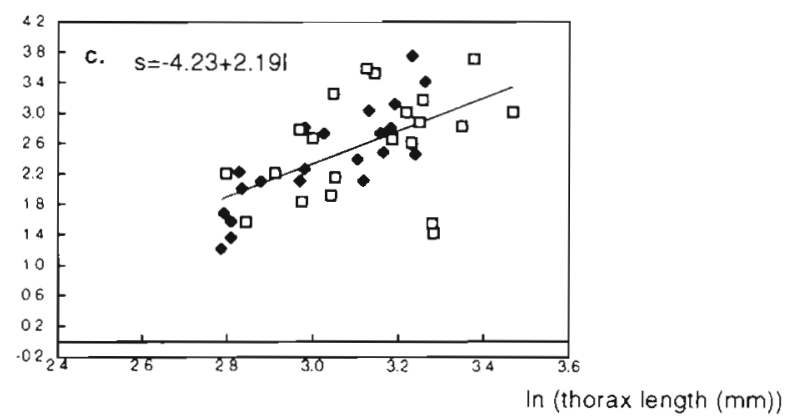

Fig. 4. Pagurus prideaux. Relationship between crab size and weight of stomach contents for the treatment wayline (a) and control wayline $(\bullet)$; where a fitted line is shown, this is a common line fitted to the whole dataset. Also showing equations for fitted line where $s=\ln \mid$ dry weight of stomach contents (mg)] and $1=\ln [$ crab thorax length $(\mathrm{mm})]$. (a) Before fishing: (b) $1 \mathrm{~d}$, (c) $2 \mathrm{~d}$, (d) $3 \mathrm{~d}$, (e) 4 d after fishing

polychaetes than $P$. bernhardus (Tables $5 \& 6$ ). P. bernhardus also appeared to have a more diverse diet than $P$. prideaux (mean number of phyla identified per stomach: $P$. bernhardus $2.8 \pm 0.16, P$. prideaux $2.3 \pm$ 0.14 ; $t$-test $p<0.001$; Shannon diversity index: $P$. bernhardus $0.85, P$ prideaux 0.77 ).
The MDS ordination plot indicated that the diets of Pagurus bernhardus collected on the trawled wayline the first day after fishing had the least similarity to those collected on the control waylines (Fig. 5). This difference appears to be due to an increase in the proportions of crustaceans and polychaetes in the diet (Table 5).

Table 6. Pagurus prideaux. Diet composition. Percentage points for each group in the stomach contents

\begin{tabular}{|c|c|c|c|c|c|c|c|c|c|c|}
\hline $\begin{array}{l}\text { Days before/ } \\
\text { after fishing }\end{array}$ & Wayline & $\begin{array}{l}\text { Crusta - } \\
\text { ceans }\end{array}$ & $\begin{array}{l}\text { Poly- } \\
\text { chaetes }\end{array}$ & Molluscs & $\begin{array}{l}\text { Echino- } \\
\text { derms }\end{array}$ & Hydrouds & $\begin{array}{l}\text { Bryo- } \\
\text { zoans }\end{array}$ & $\begin{array}{l}\text { Forami- } \\
\text { niferans }\end{array}$ & Eggs & $\begin{array}{l}\text { Unidenti- } \\
\text { fied }\end{array}$ \\
\hline \multirow[t]{2}{*}{ Before } & Control & 7.9 & 3.2 & 17.3 & 0.7 & 0.0 & 0.4 & 1.0 & 0.0 & 69.4 \\
\hline & Treatment & 8.0 & 7.4 & 10.1 & 0.1 & 0.0 & 0.4 & 1.9 & 0.0 & 72.0 \\
\hline \multirow[t]{2}{*}{$1 \mathrm{~d}$ after } & Control & 10.3 & 3.0 & 10.0 & 0.0 & 0.0 & 0.3 & 1.0 & 0.3 & 75.2 \\
\hline & Treatment & 23.8 & 8.2 & 10.7 & 0.8 & 0.1 & 0.7 & 1.1 & 0.0 & 54.6 \\
\hline \multirow[t]{2}{*}{$2 d$ after } & Control & 4.5 & 4.9 & 13.1 & 0.0 & 0.0 & 0.7 & 1.3 & 0.0 & 75.7 \\
\hline & Treatment & 18.3 & 7.7 & 11.2 & 0.9 & 0.0 & 0.2 & 1.2 & 0.0 & 60.5 \\
\hline \multirow[t]{2}{*}{$3 \mathrm{~d}$ after } & Control & 6.1 & 3.0 & 21.2 & 0.9 & 0.0 & 0.0 & 0.5 & 0.0 & 68.4 \\
\hline & Treatment & 8.8 & 5.8 & 14.4 & 4.0 & 0.1 & 0.1 & 0.3 & 0.7 & 65.7 \\
\hline \multirow[t]{2}{*}{$4 \mathrm{~d}$ after } & Control & 11.1 & 11.1 & 7.4 & 1.1 & 0.3 & 0.3 & 2.0 & 0.0 & 66.7 \\
\hline & Treatment & 7.3 & 8.5 & 11.2 & 3.0 & 0.3 & 0.1 & 1.0 & 0.0 & 68.4 \\
\hline
\end{tabular}




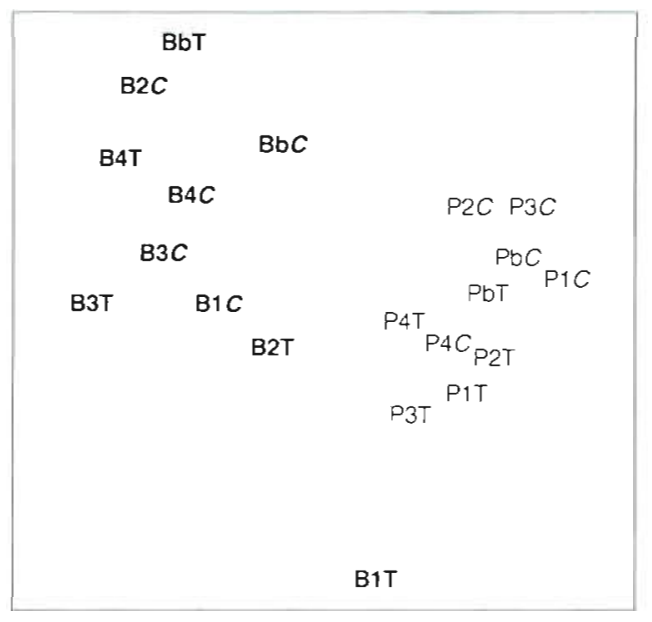

Fug. 5. Pagurus bernhardus, $P$. prideaux. MDS plot showing groupings based on stomach contents (stress $=0.14$ ). Nomenclature $(\mathrm{XYZ})$ as follows: $\mathrm{X}=$ species $(\mathrm{B}=P$. bernhardus, $\mathrm{P}=P$. prideaix $), y=$ days beforc $y$ after fishing $(b=$ before, $1=1 \mathrm{~d}, 2$ $=2 \mathrm{~d}, 3=3 \mathrm{~d}$, and $4=4 \mathrm{~d}$ after $), \mathrm{Z}=$ wayline $(C=$ control, $\mathrm{T}=$ treatment)

\section{DISCUSSION}

Our results demonstrate that Pagurus bernhardus respond strongly to trawling disturbance, rapidly migrating onto a trawled wayline and increasing their food intake whilst in that area. However, no similar response was detected for $P$. prideaux

The mean density of Pagurus bernhardus in the trawled area was significantly higher than in the control areas 2 and $3 \mathrm{~d}$ after fishing. The mean density of hermit crabs peaked after $2 \mathrm{~d}$, decreasing on the third day, suggesting that $P$. bernhardus were migrating into the trawled area for $2 \mathrm{~d}$ following fishing.

The proportion of large Pagurus bernhardus was much greater in the trawled area than in the adjacent controls. This may be due to either size-specific differences in rates of migration, or to competitive exclusion of smaller crabs. Competitive exclusion of smaller $P$. bernhardus occurs when intraspecific competition for food becomes intense (Ramsay et al. 1997), however, in this study, we have no direct measure of the intensity of competition in the trawled area. It seems likely that larger $P$. bernhardus would move faster over longer distances, and may thus arrive more quickly in the trawled area.

Pagurus bernhardus caught in the trawled area consumed more food than those in the adjacent untrawled areas. This suggests that the migration onto the trawled wayline is a response to increased food availability as a result of trawling disturbance. Within the range studied, the amount of extra food gained by foraging in the trawled area increased with increasing crab size [indicated by the parallel lines fitted to the relationship between $\ln$ (crab size) and $\ln$ (dry weight of stomach contents)]. The estimated amount of extra food consumed by a crab with a thorax length of $22 \mathrm{~mm}$ (the mean thorax length in this study) varied from $5.7 \mathrm{mg}$ dry wt (1 d after fishing) to $4.9 \mathrm{mg}$ dry wt (3 d after fishing)

Changes in dietary composition for Pagurus bernhardus collected on the fished wayline occurred on the first day after fishing. This change was expressed as an increase in the proportions of crustaceans and polychaetes in the diet. Although difficult to identify with certainty, the majority of crustaceans in the diet appeared to be amphipods, and the more identifiable polychaetes appeared to be Lagis koreni. Kaiser \& Spencer (1994) found that gurnards and whiting feeding in areas disturbed by fishing increased their intake of the amphipod Ampelisca spinipes. A. spinipes is a tube dwelling species and Kaiser \& Spencer (1994) postulated that trawling may disturb the ampipod from its tube, making it more vulnerable to predation. $L$. koreni is encased within a brittle tube constructed of sand grains and lives at the sediment/water interface. Consequently it is vulnerable to damage and displacement by trawling. It seems likely that the increase in stomach content weights after fishing is at least partly due to $P$. bernhardus feeding on infaunal animals which have been exposed or damaged by the action of the beam trawl, making them easier to find and capture than would normally be the case. It might be expected that $P$. bernhardus would feed on larger items which have been damaged by the beam trawl, such as soft tissues of. Spatangus purpureus, Ensis spp. or Laevicardium sp. which have been found in fish stomachs on trawled areas (Kaiser \& Spencer 1994). However, if this were so, one would expect the results to show an increase either in those taxa or in the proportion of unidentified digesta. No such result was obtained, which suggests that the crabs were mainly feeding on smaller infaunal animals that were damaged or exposed by the beam trawl.

It appears that Pagurus prideaux neither migrate into trawled areas nor obtain more food from within the trawled area. The increased numbers of $P$. prideaux on the control wayline $3 \mathrm{~d}$ after fishing was unexpected. The control wayline catches contained higher numbers of small crabs than the trawled wayline, suggesting aggregations of small individuals. However, the possible reasons for these aggregations are unclear.

The different responses of the 2 species to trawling disturbance could result from either competitive interactions or niche separation. It is possible that Pagurus bernhardus is competitively superior to $P$. prideaux, excluding the latter from the resource-rich areas of recently trawled ground. The alternative possibility is 
that whilst $P$. bernhardus readily adopts the role of scavenger, $P$. prideaux is less likely to do so. Although the diets of both species include the same taxa, $P$. prideaux appears to consume a larger proportion of molluscs but fewer polychaetes compared with $P$. bernhardus. The diversity of the diets also appears to differ between species, with $P$. bernhardus frequently consuming other taxa in addition to crustaceans, molluscs and polychaetes, such as hydroids, echinoderms and bryozoans. This could indicate that $P$. bernhardus is a more generalist predator and scavenger than $P$. prideaux. A more detailed study of the diet of the 2 species, identifying prey to species level, would be necessary to draw any firm conclusions on this point. However, $P$, bernhardus does have a wider geographical and depth distribution than $P$ prideaux and may therefore occupy a broader niche-space. It is also possible that olfactory abilities differ between the 2 species, with $P$. bernhardus being better at sensing damaged prey in the trawled area.

The present study suggests that Pagurus bernhardus gain a significant amount of extra food by foraging in areas disturbed by beam trawling, and other studies have shown that $P$. bernhardus feed on fisheries discards (Kaiser \& Spencer 1996a, Ramsay et al. in press). It has been suggested that where fisheries activity increases the food supply to a predator population, an expansion of that population might occur (Furness 1984, Furness et al. 1988, Berghahn 1990, Wassenburg \& Hill 1990, Kaiser \& Spencer 1995), especially for species where the mortality due to fishing is low, as is the case for $P$. bernhardus (Fonds 1994, Kaiser \& Spencer 1995). Previous work has shown that increasing the food supply to 3 different crab species led to an increase in the fecundity in the population (Fusaro 1978, Wenner et al. 1987). However, neither of these studies linked this increase in fecundity to increased adult population size. Mortality in 1 or several of the planktonic developmental stages and dispersal of larvae may play an important part in the population dynamics of many marine invertebrates (Morgan 1995) and may be more important than the supply of food to adults. It is also possible that the availability of empty shells is an important controlling factor in hermit crab populations (Vance 1972), in which case increasing the food supply to the adult population would make little difference. However, if food availability in the adult stage is a controlling factor in populations of $P$. bernhardus it is possible that beam trawling could lead to increased population densities of this species. Further work is required to elucidate the relationship between feeding behaviour and population dynamics of other predatory species before conclusions can be drawn as to whether this is a mechanism by which fishing may cause longterm changes in benthic community structure
Acknowledgements. We thank the officers, crew and scientific staff on board RV 'Corystes' during April and October 1995 for their help. We also thank Dr Rohan Holt for assisting with the identification of stomach contents. Five anonymous referees provided helpful comments which improved the text The study was funded by the EC as part of the IMPACT II project, contract number AIR 94-11664.

\section{LITERATURE CITED}

Berghahn R (1990) On the potential impact of shrimping on trophic relationships in the Wadden Sea. In: Barnes $M$, Gibson RN (eds) Trophic relationships in the marine environment. Proc 24th Eur Mar Biol Symp. Aberdeen University Press, Aberdeen, p 130-140

Bergman MJN, Hup M (1992) Direct effects of beam trawling on macrofauna in a sandy bottom sediment in the southern North Sea. ICES J Mar Sci 49:5-11

Bergman MJN, Santbrink JW van (1994) Direct effects of beam trawling on macrofauna in sandy areas off the Dutch coast. In: de Groot SJ, Lindeboom HJ (eds) Environmental impact of bottom gears on benthic fauna in relation to natural resources management and protection of the North Sea. Netherlands Institute for Fisheries Research (NIOZ) Report 1994-11, Den Burg, Texel, p 179-208

Blaber SJM, Wassenberg TJ (1989) Feeding ecology of the piscivorous birds Phalacrocorax varius, $P$. melanoleucos and Sterna bergii in Moreton Bay, Australia: diets and dependence on trawler discards. Mar Biol 101:1-10

Clarke KR, Warwick RM (1994) Change in marine communities: an approach to statistical analysis and interpretation. Natural Environmental Research Council, Plymouth Marine Laboratory, Plymouth

Craeymeersch JA (1994) Environmental impact of bottom gears on benthic fauna in relation to natural resources management and protection of the North Sea. In: de Groot SJ, Lindeboom HJ (eds) Environmental impact of bottom gears on benthic fauna in relation to natural resources management and protection of the North Sea. Netherlands Institute for Fisheries Research (NIOZ) Report 1994 11, Den Burg, Texel, p 209-236

Erri Babu D (1988) 'Glandular pockets' of the integument and feeding mechanism in Pagurus bernhardus (Crustacea: Anomura). Mar Biol 99:315-323

Fonds $M$ (1994) Mortality of fish and invertebrates in beam trawl catches and the survival chances of discards. In: de Groot SJ, Lindeboom HJ (eds) Environmental impact of bottom gears on benthic fauna in relation to natural resources management and protection of the North Sea Netherlands Institute for Fisheries Research (NIOZ) Report 1994-11, Den Burg, Texel, p 131-146

Freıre J, Fernández L, González-Gurriarán E (1991) Diel feeding pattern of Liocarcinus depurator (Brachyura: Portunidae) in the Ria de Arousa (Galicia, NW Spain). Ophelia 33:165-177

Furness RW (1984) Seabird-fisheries relationships in the north-east Atlantrc and North Sea. In: Nettleship DN, Sanger GA, Springer PF (eds) Marine birds: their feeding ecology and commercial fisheries relationships. Canadian Wildlife Service Special Publication. Dartmouth, Nova Scotia, p 162-169

Furness RW, Hudson AV, Ensor K (1988) Interactions between scavenging seabirds and commerclal fisheries around the British Isles. In: Burger J (ed) Seabırds and other marine vertebrates: competition, predation and other interactions. Columbia University Press, New York, p 240-268 
Fusaro C (1978) Food availability and egg production: a field experiment with Hippa pacifica Dana (Decapoda, Hippidae). Pac Sci 32:17-23

Gerlach SA, Ekstrom DK, Eckardt PB (1976) Filter feeding in the hermit crab Pagurus bernhardus. Oecologia 24: $257-264$

Hudson AV, Furness RW (1988) Utilization of discarded fish by scavenging seabirds behind whitefish trawlers in Shetland. J Zool (Lond) 215:151-166

Hynes HBN (1950) The food of freshwater sticklebacks (Gasterosteus aculeatus and Pyosteus pungitius) with a review of methods used in studies of the food of fishes. J Anim Ecol 19:36-58

Jackson HG (1913) Eupagurus. LMBC Mem Typ Br Mar PL Anim 21:1-79

Kaiser MJ, Rogers SI, McCandless DT (1994) Improving quantitative surveys of epibenthic communities using a modified $2 \mathrm{~m}$ beam trawl. Mar Ecol Prog Ser 106:131-138

Kaiser MJ, Spencer BE (1994) Fish scavenging behaviour in recently trawled areas. Mar Ecol Prog Ser 112:41-49

Kaiser MJ, Spencer BE (1995) Survival of by-catch from a beam trawl. Mar Ecol Prog Ser 126:31-38

Kaiser MJ, Spencer BE (1996a) Behavioural responses of scavengers to beam trawl disturbance. In: Greenstreet SPR, Tasker ML (eds) Aquatic predators and their prey. Blackwell Scientific Publications, Oxford, p 116-123

Kaiser MJ, Spencer BE (1996b) The effects of beam-trawl disturbance on infaunal communities in different habitats J Anim Ecol 65:348-358

Morgan SG (1995) Life and death in the plankton: larval mortality and adaptation. In: McEdward L (ed) Ecology of marine invertebrate larvae. CRC Press, Boca Raton, p 279-321

Nickell TD, Moore PG (1992) The behavioural ecology of epibenthic scavenging invertebrates in the Clyde Sea area: laboratory experiments on attractions to bait in moving water, underwater TV observations in situ and general

This article was submitted to the editor conclusions. J Exp Mar Biol Ecol 159:15-35

Orton JH (1927) On the mode of feeding of the hermit-crab Eupagurus bernhardus, and some other Decapoda. J Mar Biol Ass UK 14:909-921

Pike RB, Williamson DI (1959) Observations on the distribution and breeding of Bntish hermit crabs and the stone crab (Crustacea: Diogenidae, Paguridea and Lithodae) Proc Zool Soc Lond 132:551-567

Ramsay K, Kaiser MJ. Hughes RN (1997) A field study of intraspecific competition for food in hermit crabs (Pagurus bernhardus). Estuar Coast Shelf Sci 44:in press

Santbrink JW van, Bergman MJN (1994) Direct effects of beam trawling on macrofauna in a soft bottom area in the southern North Sea. In: de Groot SJ, Lindeboom HJ (eds) Environmental impact of bottom gears on benthic fauna in relation to natural resources management and protection of the North Sea. Netherlands Institute for Fisheries Research (NIOZ) Report 1994-11, Den Burg, Texel, p 147-178

van Beek FA, van Leeuwen PI, Rijnsdorp AD (1990) On the survival of plaice and sole discards in the otter-trawl and beam-trawl fisheries in the North Sea. Neth J Sea Res 26 $151-160$

Vance RR (1972) Competition and mechanism of coexistence in three sympatric species of intertidal hermit crabs. Ecology 53:1062-1074

Wassenberg TJ, Hill BJ (1987) Feeding by the sand crab Portunus pelagicus on material discarded from prawn trawlers in Moreton Bay, Australia. Mar Biol 95:387-393

Wassenberg TJ, Hill BJ (1990) Partitioning of material discarded from prawn trawlers in Moreton Bay. Aust $J$ Mar Freshwater Res 41:27-36

Wenner AM, Ricard Y, Dugan J (1987) Hippid crab population structure and food availability on Pacific shorelines. Bull Mar Sci 41:221-233

Williams MJ (1981) Methods for analysis of natural diet in portunid crabs (Crustacea, Decapoda, Portunidae). J Exp Mar Biol Ecol 52:103-113

Manuscript first received: July 9, 1996

Revised version accepted: October 14, 1996 